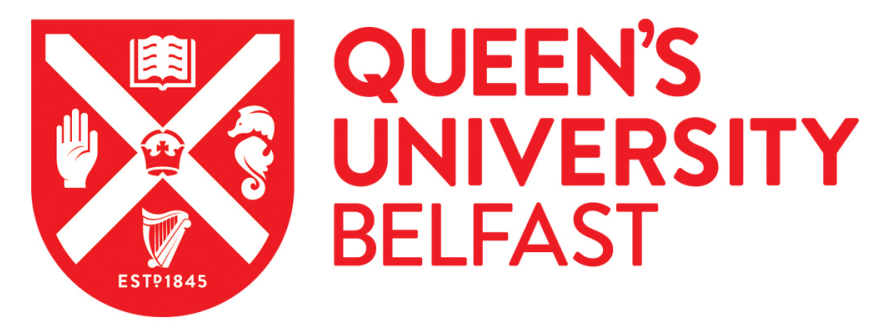

\title{
Valuing the talk of young people: are we nearly there yet?
}

O'Boyle, A. (2013). Valuing the talk of young people: are we nearly there yet? London Review of Education, 11(2), 127-139. https://doi.org/10.1080/14748460.2013.799809

Published in:

London Review of Education

Document Version:

Peer reviewed version

Queen's University Belfast - Research Portal:

Link to publication record in Queen's University Belfast Research Portal

Publisher rights

Copyright 2013 Institute of Education, University of London.

This work is made available online in accordance with the publisher's policies. Please refer to any applicable terms of use of the publisher.

\section{General rights}

Copyright for the publications made accessible via the Queen's University Belfast Research Portal is retained by the author(s) and / or other copyright owners and it is a condition of accessing these publications that users recognise and abide by the legal requirements associated with these rights.

Take down policy

The Research Portal is Queen's institutional repository that provides access to Queen's research output. Every effort has been made to ensure that content in the Research Portal does not infringe any person's rights, or applicable UK laws. If you discover content in the Research Portal that you believe breaches copyright or violates any law, please contact openaccess@qub.ac.uk. 


\section{Valuing the talk of young people: are we nearly there yet?}

Aisling O’Boyle

a School of Education, Queen's University Belfast,

\section{Abstract}

This paper examines reasons why young people's talk about themselves and their educational experiences do not seem to be valued in public discourse about education. Drawing on a national dataset of student focus groups, it illustrates how students talk about themselves in educational contexts in a way that is entirely different and more complex than how they are conceptualised by an adult audience and symbolic elites. It demonstrates, contrary to dominant adult perceptions, the critical, communicative and creative use of language offered by young people when asked about their educational experiences, and highlights the potential innovation being missed by not listening.

\section{Keywords:}

Teenage talk, the language of young people, voice, public discourse

\section{Note on author}

Aisling O'Boyle is a lecturer at the School of Education, Queen's University Belfast. Her research interests include discourse in educational contexts, spoken academic discourse, classroom talk and TESOL.

Contact details: 69-71 University Street, Belfast, U.K. BT7 1NN. Email: a.oboyle@qub.ac.uk 


\title{
Listening, but not hearing
}

\author{
"Those groups who are in control of the most influential public discourses, that is the symbolic elites \\ such as politicians, journalists, scholars, teachers, and writers, play a special role in the reproduction \\ of dominant knowledge and ideologies in society" (Van Dijk 2012,17)
}

In the past ten years there have been moves to make the voices of students heard in relation to matters of their schooling and education (Rudduck, 2002; Rudduck et al., 2003; Leitch et al., 2007) and heard by those who are in control of the most influential public discourse, in order to affect change for the better. The concept of 'student voice' was thought to have the potential to substantially transform young people's lives and their schools. It was argued that actively listening to what students say about their educational experiences would have improving and empowering effects, such as an increase in student self-worth, self-respect and learning, and a greater sense of personal and political agency as a result (Rudduck, 2002). As Elwood (2013) highlights in this issue, these moves to ensure that students' voices are heard have been underpinned by Children's Rights legislation. Translated into government policy, this assurance on the rights of the child requires schools, colleges, and educational centres to demonstrate how students' views are taken into account in the running of their institution. In practice, statutory guidance advises schools to encourage young people to participate in school councils and youth parliaments. However, as Elwood (2012) notes, school councils are often considered by young people as tokenistic; their views are listened to, but are not influential. Although schools may consult young people, it may only be in relation to minor matters. 
Despite legal and moral imperatives to consult young people, to listen to and act upon the views expressed, current practice and policy do not seem to legitimise the voices of young people as substantively as initially intended (Lundy, 2007).Concern exists in the area of 1419 education in relation to the absence of student voice in policy debate (Lumby and Foskett, 2005). Indeed, in recent reviews of education for 14-19 year olds, there remain calls to "re-distribute [...]power and decision-making, such that there can be greater room for the voice of the learner" (Pring et al. 2009, 4) and to ensure that the value which students place on educational programmes is taken into account in any development thereof (Wolf, 2011). In relation to the most significant aspects of education during this phase, qualifications and assessment, the impact of student views on these matters is barely traceable, if at all present (Elwood and Lundy, 2010; Elwood, 2012).

So, why then are the voices of young people so difficult for symbolic elites to hear? When young people talk, why does no one seem to listen? It may be that the talk of young people is not being afforded equal weight in public discourse and consultation because young people's talk is perceived as not as legitimate as adult talk and it is therefore of less value. In this paper, I suggest that the everyday notions of young people's talk influence it's perceived value in public consultation. From a broader social perspective, the devaluing of young people's linguistic capital (Bourdieu, 1999) may make it easier for symbolic elites to ignore, or discount, their views. In doing so, a dominant ideology of young people as objects rather than social actors is continually reproduced.

\section{Position and evidence}


To illustrate these arguments, I will focus on how young people talked about themselves and their educational experiences during student focus groups carried out as part of a national study. The study investigated the impact of the 14-19 educational reforms on schools and colleges across England (Baird et al., 2011) and involved 52 educational institutions (including schools, colleges, academies, special education centres and specialist colleges) in a collective instrumental case study. Focus groups and interviews were carried out with a range of stake-holders (students, teachers, curriculum managers, parents, governors and principals) in 18 of the institutions during 3-day case study visits over the period of $2009 / 10$. The methodological approach and a report of the findings of the case study are reported in Baird et al. (2011).

In this paper, I draw on the 45 transcripts of student focus groups. The focus groups were conducted with over 240 students attending the educational institutions and were designed to gather information on students' experiences of reforms, consultation, qualifications, pathways, choice, and what they considered to be the most important aspect of schooling. In order to be able to investigate how young people talk about themselves and how they talk about their educational experiences, the approach taken to the analysis of the data in this paper, necessarily shifts in perspective from that reported elsewhere (Baird et al., 2011Elwood, 2012). Here, I carry out a discourse analysis of the student focus group transcripts in order to i) examine how students talk about themselves and their experiences, and ii)investigate the social question of why the talk of young people is not listened to by symbolic elites. Thus, this investigation can be positioned using Hornberger's (1989) typology of research methods in Language and Education, as a micro-level analysis of language, from a macro-level societal perspective. The methodological stance taken to the 
research interview is not only one which considers it as an instrument to access ideas and opinions, but as a form of social practice (Talmy, 2010), and the transcriptions of recordings are viewed as discourse (Brown and Yule, 1983).Although there are a range of approaches to discourse analysis (see Hammersley, 2002), the central principle of any discourse analysis is a focus, not only on what is said, but how it is said. An analysis of the words chosen to express and engage in action can be a way of seeing how conceptual worlds have been constructed (Scollon, 2006; Cameron, 2003). In addition, an examination of the interactional positions of speakers (Du Bois, 2006) allows for a greater understanding of how the knowledge presented in the interview has been constructed by young people talking to researchers.

\section{Future existence and normative homogenous transition}

A critical examination of common and every day understandings (Scollon, 2006) of young people offers some understanding as to why their linguistic capital is devalued. There is a notion of youth as immaturity, which persists in contemporary society's narrative of young people (Arnett, 2000), and it is embedded in the fixation on a young person's future existence rather than their current state. This notion materialises in the understanding that young people move from a period of immaturity to a period termed adulthood. Although a seemingly uncontroversial position, this notion relies upon a number of assumptions which could be much questioned. The first of these is that adulthood is a fixed and static concept. To the contrary, Stables (2012) suggests that the nature of adulthood in contemporary society is much less fixed than in previous ages. Jobs are no longer for life, and career paths 
change. A person's judgements and opinions are now much more variable and likely to change. Despite all manner of significant events and lifespan factors which can impact on an individual's personality or identity at any time, even adult identities are considered more static than young peoples' identities (Thurlow and Marwick, 2005). Given that adults are also in a state of transition over their lifespan, it seems that any notion built on the premise of preparation for a "settled period as adult citizen" (Stables 2012, vii) may be simplistic. Overstated descriptions of adulthood as unwavering and stable minimise the fundamentally shared characteristic of people of different ages, which is that we all exist as social and human beings who share space and time in the here and now (Stables, 2012). Such exaggerated differences between people of different ages consequently construes communication between groups of different ages as "intergroup" communication (Thurlow, 2005) and further perpetuates the idea of a "generation gap", despite very little evidence for it (Coleman, 2011).

Second, the notion of youth as immaturity is given attention around the globe (Smith et al. 2002) and particular attention is focussed on whether or not young people succeed or fail to make a "normative transition to adulthood" (Wyn 2005, 30). Such a transition is not simply a natural, unguided one, based on a biological order of events. It is also based upon a social construction of the "periodization of life course "(James and Prout 1997, 234) and the cultural homogenization of young people in contemporary societies. Taken at face value, the term '14-19 education' used in the UK context seems a neutral one. It highlights the start of life choices at one end of the period and the move out of education at the other (Pring et al., 2009). In general, however, any age-related category points to the periodization of life and identifies the groupings used to structure and govern people in 
society (James and Prout, 1997). It has long been noted that it is during these teenage years, in particular, that social order is administered by industrialized societies who push similarly aged groups of young people together (Eckert, 1997; Thurlow, 2007). Arguably, this simply represents contemporary society's desire to ensure that all young people are prepared for the challenges of adulthood. However, it can also be argued that such phases of education permit the consolidation of a sociopolitical position which homogenises young people for socioeconomic effects. The homogenisation of young people can lead to an assumption that they are one group and speak with one 'voice'. Although young people between the ages of 14-19 may share some views, this does not necessarily entail that they are all share the same wants and needs throughout this particular periodization of their lives. Sustaining one dominant view of young people eliminates the need to listen out for the variation which does and can exist. Although variation may be perceived as problematic in relation to the processes of institutionalization and the administration of social order, variation has the potential to create new and different ways of thinking. The inhibition of variation and the failure to listen to the innovation which it can produce limits any existing potential. One dominant view of young people therefore allows very little room for the variety of social capital that could exist.

As an item of public discourse, in which no one individual author is responsible for its creation and can therefore not be challenged to defend its relevancy or truthfulness (Scollon, 2006), the term '14-19' is much used to describe this group of young people with reference to their life experiences in or out of educational institutions. In the analysis of the 45 focus groups with young people undertaken for this paper, it is notable that they did not speak about themselves in the terms used by symbolic elites. A search of all the words used 
in the transcripts using computer software (Wordsmith Tools, Scott, 2005) shows that students do not use this term for any self-reference. Equally, self-reference using the term 'young people' is not common in the transcripts. In the 136 instances of the term young people, only 5 are uttered by students. In the instances where this phrase is used it either positions the speaker from a point in the future, that is, as a voicing from an adult perspective, or it is used to draw a distinction between the speaker and someone they consider to be in a different group. An extract from one of the instances of students referring to themselves as young people is presented below to illustrate the more complex distinctions that young people make between themselves.

In Extract 1, the interviewer moves to initiate a new topic using a general question (young people, line 1-2) which is followed by a more specific question in the same turn (you, line 3). This shift from general to specific is taken up by Male Speaker 1 in line 4 as a distinction between him and unknown others (for us) and those at a different stage (whereas for first years). Further in line 10, another student (Female Speaker 2 ) returns to this distinction set up in the question and triggered by the use of young people (line 1). In this instance, the difference is drawn much deeper, positioning young people (line 11) as those who go to school. In so doing, the speaker not only excludes the term as a point of reference for herself, but also draws to her stance all the other students present in her description and distinction of them as college-goers (for us, line 11).

\section{Example 1}

1 Male Interviewer:

2

3

$4 \quad$ Male Speaker 1:
Okay, thank you. What do you think are the most important things that young people are concerned about at this particular age of their education? What most concerns you about your education right now? For us, I think it would probably be university, whereas for first years, I'm 
6 Interviewer:

7 Male Speaker 1:

8 Female Speaker 1:

9

10 Female Speaker 2:

11

12 not too sure.

What do you mean about university?

Like, if we get into the uni that we want, money, travel, yeah.

I think it's just what next in general, I mean, what do you do after you leave here.

Yeah, that's what I was asking, yeah. Is it in general, or just like in colleges, for everyone like young people in high school or is it just asking for us in college?

These distinctions around self-reference and groupings are more subtle than the more lexically orientated and colourful descriptions and distinctions of young social groups such as nerds, jocks, and burnouts as found in other studies (Eckert, 1997; Bucholtz, 1998). An examination of the word list created from all the interview transcripts shows that those types of labels are also present in this dataset, e.g. nerds, snobby people, stuck-up people and boffs. Again, these types of referents are used by the speakers in these focus groups to draw finer-grained distinctions between all those who fall within the same 14-19 periodization of life. Their talk about themselves illustrates more complexity and variation than public discourse about young people might suggest.

\section{Objects rather than actors}

Although the 14-19 phase of education was first developed to focus on a comprehensive and coherent system of education in England (Hodgson and Spours 2003), it has become a "high-stakes battlefield" with competing expectations (Lumby and Foskett 2005, 5). In the current UK context, 14-19 education is marked by discussions framed in fear of not achieving social order or not fulfilling the apparent wants of contemporary society, and thus 
has become a highly politicised one (Raffe and Spours, 2007). Noted by Hodgson and Spours' (2011), this phase of education is characterised, in the discourse of symbolic elites, by concern: about attainment and ill-favoured international comparisons; about participation and growing numbers of young people not in education, employment or training; and about rising youth unemployment in an unpredictable labour market. The politicised and thereby negative and problematic narrative surrounding young people in this phase of education in the UK is an example of how postmodern democratic societies seem to objectify their young people in public discourse. Social theorists, such as Giroux (2000), critique contemporary societies in relation to how they treat young people, whether educated, undereducated or uneducated, arguing that young people are conceptualized on the one hand as threats to social order, and on the other hand as disposable commodities. Once conceptualized as an object of any kind, be it an object of fear or one exploitable for economic gain, it becomes very difficult to redrawthe conceptual mapto one of young people as social actors with agency.

In their focus group discussions about relationships with teachers, preparation for exams, and the semblance of their own decision-making, there is evidence of how young people echo these societal conceptualizations through their choice of words and phrases. They talk about themselves in educational contexts not as human beings growing or developing, but as objects being manufactured through physical processes and movement. In the examples below, the metaphors they use to describe themselves and the process of education are highlighted in bold. The three examples come from different speakers in different transcripts. 
a. drumming all this stuff into us over and over and over and over again

b. it's obviously hammered into us and our whole life

c. you kind of getpushed towards one subject and you don't want to do it but then because you're getting constantly pushed into your strengths, even if you want to improve on another part of your schooling you just sort of go 'mah' and get pushed where you're going and you just go with it, head down, just go.

The way in which they talk about themselves as mouldable objects, seems to reflect some sense that they are under a degree of administration of social order. Not only is this reflected in word choice, but also in the grammatical structures that they choose to describe their situations. The use of pseudo-passives (get pushed)illustrates both the lack of personal agency on their part and the irritation sensed by it. The extract below shows further examples of these features (highlighted in bold) in the context of interaction, and illustrates how the speakers construct their experiences and given an evaluation of them. Just before this extract starts, the researcher has asked: "Do you think the qualifications that are offered here, and the type of learning that's offered here, do you think that meets the needs of everybody here?"Students, responding to the universality implied in the question (everybody), discuss at some length how their institution does not treat everyone the same, how they consider a number of its practices unfair, before the following occurs:

Example 3

1 Female Speaker 1: I think they should like talk more about what people want to do instead of just saying you're going to do what you want to do but we want you to do this for now.

4 Female Speaker 2: $\quad$ And because like ... they just assume that you're really good, but I don't 
7 Male Speaker 1:

8 Female Speaker 2:

9 Male Speaker 2:

10 Male Speaker 1:

12 Male Speaker 2: feel as good as like the other people, so I feel behind in English and I don't like it.

They don't treat everybody the same way do they?

Mr Milton is like "you will be getting a B", my target is only a C.

Yeah, it's being told that you will get these grades.

You get your hopes up don't you, and then you get your grade back, and you've just got a-

Its sort of like being told that, you get given your target, but then you're told that you will get, you know, one or two grades above that, and it's like, but I can't, it may make you look good, but this is what I'm going for, because this is what I've been told I can get.

Yeah, that's the thing, they, like we did our English exam, and I got the grade that I needed, and they tried to push me onto doing it again, to try and get better grades, so I said I don't want to do it, I've got the grade that I need, why do it again?

It is not just in their use of figurative language that young people express the sense of themselves as objects to which things are done, they express this experience through other means. They describe things that happen to them using passive and psuedo passive structures (get given your target, line12; been told I can get; line 15). The person responsible is not salient in the interaction and is assumed to be obvious, but this choice of language use signals how young people themselves have had no control in making these decisions about 'targets'. In some respects, their agency in achieving these targets is also diminished, given the directives and commands (indirect or otherwise: We want you to do this, line 2) about their future (you will get, line 13). 


\section{Teenage stereotype: negative social attitudes to the talk of young people}

From Kevin the Teenager to Vicky Pollard to Lauren Cooper's conversation with then Prime Minister Tony Blair, teenage talk is largely a source of amusement, frivolity and scorn for adults. Thurlow (2007) argued that adult controlled media plays a significant role in misrepresenting young people's communication and stereotyping this particular group. Indeed, on all the occasions when the word teenager occurs in the student focus group transcripts, students use it purposefully to invoke a teenager stereotype, which is understood to be someone who challenges an adult social order. In relation to their language use, young people are often portrayed as unintelligible to all those of a different age. The association between language and social groups is a focus of much research on language attitudes (Garrett , 2010) as judgements about language prestige reflect social attitudes (Cameron, 1995). One folk linguistic notion that persists in society, is that language is invariant. When people use language differently there is inevitably a judgement in relation to standards. An "ideology of the standard language" (Milroy 2007, 133) seeks correctness, almost independently of its language users, and it is often evident in the outcry that nonstandard language is indicative of non-standard behaviour (Garrett, 2010; Milroy, 2007). Although studies of language in use have led to a greater understanding of language as a matrix of divergent repertoires and styles, rather than as a single homogenous code (Schiffrin 1994, 21) and notions of standard ideologies and attitudes to language variation are changing in relation to the complexity of late-modern experience, (Coupland, 2010), some cultural prejudices may be slower to shift than others. 
The language of young people is presented in print and other media as degenerative, a slipping of standards, and as a threat to national levels of literacy. Scorn is often poured on their use of new media and new language practices, and again using exaggerated terms, young people are described as all new technology fanatics who only communicate using new media (Thurlow, 2007).Contrary to some beliefs, language use amongst young people is not homogenous (Georgakopoulou and Charalambidou, 2011). Various youth styles exist which are related to social, cultural, and geographic differences (Herrero, 2002), and young people's language changes within the teenage period (Tagliamonte and Denis, 2008). Furthermore, teenage language has long been associated with linguistic innovation (Stenström et al. 2002). New words and ways of using language are created by the young and often appropriated by older others.

The cultural narratives on teenage language as inept and degenerative are reflected in or reflective of individual attitudes. Adults report that teenagers are more non-communicative than any other age-related group, that they find communication with teenagers more uncomfortable than with their peers or elders, and adults perceive communication with young people to be less accommodative and more self-promotional than any other agerelated group (Williams and Garrett, 2002). The description of young people's communication as self-promotional is exemplified in phrases that adults use, such as "trying to impress", "cheeky" and "overconfident" (Garrett and Williams 2005, 42).These perceptions of the language use of young people also seem to be the case with those adults in positions of authority even when they are in frequent contact with young people, who 
describe their communication as unskilled and unmotivated (Drury \& Dennison, 1999, 2000).

In both their linguistic and non-linguistic behaviour young people intensify and radicalise their positions using language as an act of identity, to play out the leitmotifs of youth on the struggle for independence and engagement with peer groups (Stenström et al., 2002,2009). However, extreme viewpoints are taken when speakers anticipate that their co-interactants will undermine their claims, or when they are in adversarial situations (Pomerantz, 1986;222 in Rampton, 2006; 279). Given that young people are aware that their language has low prestige, it is not extraordinary to expect that they may choose to employ discourse moves which counter difficulties in the communication that they experience (Drury, 2005; Buchlotz, 1999). What is specific about young people's language, and what they choose or not to say in any given context,may indeed reflect their reactions to current adult enforced choices, decisions, policies, practices and culture.

It could be arguedthat when researchers ask young people for their views, young people will only express these extreme viewpoints termed a 'whingefest' (Gorard, 2012), or, they will unwittingly or otherwise repeat what they hear adults (for example parents or teachers) saying. Although the stylised representation of others and others' voices is amply evident in studies of young people's talk (Georgakopoulou and Charalambidou, 2011), it is also much evident in other spheres of life discussed by Rampton (2009) and Coupland (2009) in relation to Bahktin's (1986) terms of 'stylisation' and 'ventriloquation'. A multi-voiced utterance, such as the exampleshighlighted in the extract below where the students 
ventriloquate the voices of their teachers, can bea useful tool of subversion, when there are few other means to exercise any form of control over happenings.

Example 4

1 Female Speaker 1: When we come it's like, 'Right, you've got to dress smart, not like you

2

3 Female Speaker 2: Yeah, 'OFSTED are in.'

4 Female Speaker 1: 'You've got to make sure your tie's always up.Twelve stripes' and all this 5

6 Female Speaker 2:

7

8

want.'

lot, whereas normally we're not like that, we're just ourselves.

Yeah.It's not like we come in like tramps.Yeah, sometimes we do have our top button done up, but they act as if we've just come in in our own clothes.It's like, we're not that bad

It is interesting to note that it may be partly due to these techniques of subversion and hyperbole, that adults label young people's communication as "overconfident" or "cheeky" (Garret and Williams, 2005). However, the voicings of others are not always undertaken to resist or subvert. Speakers can choose to incorporate them as part of their utterances to conform to particular views (Coupland, 2009).

At times when the discourse of others enters the discourse of young people in an obvious manner, this can be misinterpreted as young people simply reproducing the views of their parents or others. The implication of this misinterpretation is that it is therefore of little value to ask young people what they thinkor it becomes a reason not to afford their views the same weight as others. Research on spoken discourse and participation frameworks 
show clearly that there are many interactional positions that a speaker can take up in conversation: From the animator of the sound to the principal, the person responsible for the content, who may not be the same in both enactments (Goffman, 1981). Research following a dialogic perspective on language repeatedly demonstrates how the words of one person are re-workings of, responses to, and predictions of, the words of others (e.g. du Bois, 2007). Indeed, repeating the cultural and institutional input from teachers is a key goal of education. Educational institutions workto transmit certain forms of cultural knowledge about education which are appropriated by students. Some of these terms are expressed in these focus groups. In extracts $a$. and $c$. below, the educational terms are accompanied by vague language (and stuff) serving to downplay any authorityin the use of these terms, and signalling that the young people are aware that they are appropriating them from elsewhere. More examples exist in the dataset than presented here and are in relation to the appropriation of highly politicised terms such as OFSTED and personalised learning.

Example 5

a. Let's say, one year I had a teacher who was more suited to my learning style, and is quite engaging and stuff

b. We had to take a test to see if we're a visual kinaesthetic or Audio. Visual, kinaesthetic or audio.

c. I don't know if this is the sort of thing you're looking for, but I think lessons are very spoon-fed. They say, oh, we've got to do more independent learning and stuff, and we all agree with it, we think, 'Oh that's great,' but when it comes to doing independent learning we can't cope with it because we're not used to it, and we flounder a bit because we're a bit lost. 
Young people do not appropriate terms uncritically. Provided with a context which gives them an opportunity to speak, students produce communicative and critical comments on issues which are both crucial to them and those who make decisions in the governance of society. This runs counter to the notion of young people as non-communicative and inept communicators (Thurlow, 2005;2007; Garrett and Williams, 2005; Williams and Garrett, 2002; Drury and Dennison, 1999 ). Across the dataset of 45 student focus groups, young people were communicative and expressive. The transcripts provide evidence of their ability to construct elaborated responses, which demonstrate higher order thinking skills (e.g. Redfield \& Rousseau, 1981) on the one hand, and interactive competence on the other (e.g. Saville-Troike, 1989). An example of one elaborated response is given below. The student moves beyond recalling and recognizing information, to analysing and evaluating information. In the talk that precedes the extract, students have been responding to a visual prompt provided by the researcher. They have been discussing the reforms and the topic of the value of new qualifications arose. Choice of qualifications is a subtopic which has just been mentioned, before the speaker provides this long turn:

Example 6:

1 Male Speaker: Personally I don't agree with the fact that wedo have options earlier now, because we used to do them in Year 9 and then start GCSE in Year 10, but now it's in Year 8, andl think it's far too earlyfor some people to be deciding their GCSEs, because like this morning we were talking to some of the teachers about how employers, because of the climate, they're not just looking at your A Levels but they're looking at your GCSE results and saying how important it is, butwhen you're like 12 and 13 years old you don't know, and between the ages of 12 and 13 and leaving college, your career aspects could change so much.It has for me and it's only been a year. 
This utterance is an act of stance-taking (Du Bois, 2007). It opens with a interpersonal marker (personally, line 1), and sets up a position of disagreement to a situation; something that has happened outside of the interaction (we have options earlier now, line 1). This reference is explained and a reason is provided for this evaluation ( think it's far too early for some people, line 3). Holding and extending his turn further (because like, line 3-4) he adds information in support of his evaluative position which references external and authoritative voices (teachers about employer and they're: line 4-5). Continuing to hold his turn (but, line 6), the same position is maintained, but instead of an appeal to external authoritative voices, this evaluation is based on a generalization (Scheibman, 2007). This an appeal to solidarity with his classmates, presupposing that they will share the same expectations (when you're like 12 and 13 years old you don't know, line 6-7). Despite his attempts to make his position as credible and unbiased as possible (Potter, 1996), the speakeracknowledges his self-interest in the stance taken (It has for me and it's only been a year, line 8).Further personal evaluations are presented (I find it a bit annoying, line 9) before a final appeal and face-saving move in the direction of generalisation (that's life, line 9).

An examination of the content, structure, and interactive communicative work on display in this student's utterance shows that it is both critical and communicative. As it is not alone in the dataset, the data from these focus groupscan demonstrate how young people have the ability and insight to talk about the matters that ultimately affect them the most. 


\section{Conclusion and a way forward}

This paper has proposed reasons why young people's talk about themselves and their educational experiences do not seem to be valued in public discourse about education. The cultural narratives which surround the education of young people seem to be founded on an underlying belief of predetermination(i.e. a focus on their future state rather than current existence, a need for society to homogenize, and the objectification of young people), which in turn seems to eradicate any real need to consult with them. Furthermore,social and cultural misrepresentations of how young people talk and use language devalue their linguistic capital. If it is assumed to be below standard, it makes their talk less worth listening to. If it is perceived to be uncritical, it will only serve to tell symbolic elites things they already think they know.

However, by examining how young people talked about themselves and their educational experiences during focus groups this paper has illustrated the critical, communicative and creative use of language offered by young people, when asked, and it traces an image of young people that is entirely different and more complex than the way in which they are depicted by symbolic elites.

As Bourdieu (1999) notes, "the sense of the value of one's own linguistic products is a fundamental dimension of the sense of knowing the place which one occupies in the social space" $(1999,508)$. If the aim of education in democratic societies really is about teaching young people to become active and critical citizens (Giroux, 2000), then not listening to students still stands as a firmer barrier to this goal. 
It follows therefore, in the proposal of Giroux (2000), that the misrepresentations of youth and the politics of culture must be confronted if the desire is to understand, challenge and change the practices that shape young peoples lives. Drawing on the recommendation of Rudduck (2002), researchers ought to not only "make public students' perspectives" but also "demonstrate [...] the capability of young people to comment insightfully on issues affecting their lives and learning in school". This paper has in part, attempted to follow those recommendations. The national study, which provided the data examined, was undertaken in a manner underpinned by a social agenda: to get the voices of those most affected by reform, heard by those directing reform. This is evidenced, in part, by the range and amount of student views sought, in comparison to other more traditionally listened to stake-holders, and in the approach taken to listening to what young wanted to say during focus groups, not just on what they said about pre-planned topics. Yet, much further moves to raise the value of the talk of young people, and to ensure that due weight and influence is given to the views of children and young people could andcan be made. Approaches to educational research from a rights-based approach (Lundy, 2007; Elwood and Lundy, 2010; Lundy and McEvoy, 2012a) makes explicit any social aims of research. Such aims are then carried through the process of research by faciliating young people in forming their views and by establishing young people's advisory groups to work alongside adults in the research process (Lundy and McEvoy, 2012b). Not only can findings from such research then begin to counterbalance some of the misconceived public discourse on young people and the language of young people (Androutsopoulos, 2001) but it can also promote young people's political agency as social actors in the formation of policies that impact on their life experiences and trajectories. 


\section{References}

Alexander, R. 2012.Neither national nor a curriculum? Response to the Secretary of State's National Curriculum proposals for England, June 2012. Accessed September 2012. http://www.primaryreview.org.uk/downloads_/news/2012/06/2012_06_29NC_revie w_SoS_letter.pdf.

Androutsopoulos, J. and A. Georgakopoulou. 2003.Discourse Constructions of Youth Identities Amsterdam: Benjamins

Arnett,J. 2000. “Emerging adulthood: A theory of development from the late teens through the twenties."American Psychologist55 (5) 469-80.

Bakhtin, M. M. 1986.Speech genres and other late essays. Austin: University of Texas Press.

Baird, J., J. Elwood, G. Duffy, A. Feiler, A. O’Boyle, J. Rose, and G. Stobart. 2011.14-19 Centre Research Study. Qualifications and Curriculum Authority Report.

Bourdieu, P. 1999. "Language and Symbolic Power". In The Discourse Reader,eds. A. Jaworski and N. Coupland. London: Routledge.

Brown, G. and G. Yule. 1983. Discourse Analysis. Cambridge: Cambridge University Press.

Bucholtz, M. 1999."Why Be Normal?: Language and Identity Practices in a Community of Nerd Girls."Language in Society28(2) 203-223.

Cameron, D. 1995.Verbal Hygiene. London: Routledge.

Cameron, L. 2003.Metaphor in Educational Discourse. London: Continuum. 
CBI . 2012. Learning to Grow: what employers need from education and skills. Education and Skills Survey 2012. Accessed September 2012.

http://www.cbi.org.uk/media/1514978/cbi_education_and_skills_survey_2012.pdf.

Coleman, J.C. 2011.The Nature of Adolescence. London: Routledge.

Coupland, N. 2009.“Dialect style, social class and metacultural performance: The pantomime Dame" In The New Sociolinguistics Reader, eds.N.Coupland and A. Jaworski. Palgrave Macmillan.

Coupland, N. 2010“Language, ideology, media and social change." In Performing the Self, eds.K. Junod and D. Maillat. Tübingen: Gunter NarrVerlag.

Drury, J. 2005. "Young people's communication with adults in the institutional order." In Talking Adolescence: Perspectives on communication in the teenage years, eds.A. Williams and C. Thurlow. New York: Peter Lang.

Drury, J. and C. Dennison. 1999. “Individual responsibility versus social category problems: Benefit officers' perceptions of communication with young people."Journal of Youth Studies2, 171-192.

Drury, J. and C. Dennison. 2000. "Representations of teenagers among police officers: Some implications for their communication with young people." Youth and Policy, 66, 6287.

Du Bois, J. 2007. "The stance triangle”.In Stancetaking in Discourse, ed. R. Englebretson. Amsterdam: John Benjamins. 
Eckert, P. 1997. Why ethnography? In UngdomssprakiNorden, eds.U.Kotsinas, A. Stenstrom, and A. Karlsson. Stockholm: Stockholm University.

Elwood, J. 2013. "The role(s) of student voice in 14-19 education policy reform: reflections from students on what they are, and what they are not, consulted about" London Review of Education

Elwood, J. 2012. “Qualifications, examinations and assessment: views and perspectives ofstudents in the 14-19 phase on policy and practice."Cambridge Journal of Education 42 (4) 497-512.

Elwood, J. and L. Lundy.2010.“Revisioning assessment through a children's rights approach: implications for policy, process and practice" Research Papers in Education 25 (3) 335353

Flutter, J. and J. Rudduck. 2004. Pupil Consultation: What's in it for schools?. London: Routledge.

Garrett, P. 2010. Attitudes to Language. Cambridge: Cambridge University Press.

Garrett, P. and A. Williams. 2005. "Adults' perceptions of communication with adolescents." In Talking Adolescence: Perspectives on Communication in the Teenage Years, eds. A. Williams and C. Thurlow. New York: Peter Lang.

Georgakopoulou, A. and A. Charalambidou. 2011.“Doing age and ageing: language discourse and social interaction." In Pragmatics of Society, eds. G. Andersen and K. Aijmer. Berlin: Mouton de Gruyter. 
Giroux, H. A. 2000.Stealing Innocence: Youth, Corporate Power, and the Politics of Culture. New York: St. Martin's Press.

Goffman E. 1981. Forms of Talk.University of Pennsylvania Press.

Gorard, S. 2012. "Experiencing fairness at school: an international study in five countries" International Journal of Educational Research 3 (3) 127-137.

Hammersley, M. 2002.Educational Research, Policymaking, and Practice. London: Paul Chapman.

Hardman, F. 2008. "The guided co-construction of knowledge" In Encyclopaedia of Language and Educationeds. M. Martin-Jones, A. De Mejia, and N. Hornberger. New York: Springer Publishing.

Hayward, G. and R. Williams. 2011. "Joining the big society: am I bothered?".London Review of Education, 9 (2) 175-189.

Herrero, G. 2002.“Aspectossintácticos del lenguaje juvenil”. In El lenguaje de los jóvenes, ed. F. Rodríguez . Barcelona: Ariel.

Hodgson, A. and K. Spours. 2003.Beyond A Levels: Curriculum 2000 and the reform of 14-19 qualifications. London: Kogan Page.

Hornberger, N. H. 1989. “Continua of biliteracy”, Review of Educational Research 59 (3) 271296.

James, A. and A. Prout. 1997."Re-presenting Childhood: Time and Transition in the study of Childhood." In Constructing and Reconstructing Childhood: Contemporary Issues in 
the Sociological Study of Childhood, eds. A. James, and A. Prout, A. London: Routledge.

Leitch, R., J. Gardner, S. Mitchell, L. Lundy, O.Odena, D. Galanouli, and P. Clough. 2007. “Consulting pupils in 'Assessment for Learning' classrooms: The twists and turns of working with students as co-researchers." Educational Action Research, 15 (3) 459478.

Lumby, J. and N. Foskett. 2005. 14-19 Education: Policy, Leadership and Learning. Sage Publications: London.

Lundy, L. and L.McEvoy (Emerson). 2012a. “Childhood, the United Nations Convention on the Rights of the Child and Research: What Constitutes a 'Rights-Based' Approach?" InLaw and Childhood,ed. M. Freeman. Oxford: Oxford University Press.

Lundy, L. and L.McEvoy (Emerson). 2012b. “Children's rights and Research Processes: assisting children to (in)formed views".Childhood, 19(1) 116-129.

Milroy, J. 1992. Linguistic variation and change. Oxford: Blackwell.

Potter, J. 2006. Representing Reality: Discourse, Rhetoric, and Social Construction. London: Sage.

Pring, R., G. Hayward, A. Hodgson, J. Johnson, E. Keep, A. Oancea, G. Rees, K. Spours, and S. Wilde. 2009.Education for all: the future of education and training for 14-19 year olds. London: Routledge. 
Raffe, D., and K. Spours. 2007. Policy-making and policy learning in 14-19 education. London: Institute ofEducation, University of London Bedford Way Papers.

Rampton, B. 2006.Language in Late Modernity: Interaction in an Urban School. Cambridge: Cambridge University Press.

Redfield, D. L. and E.W. Rousseau. 1981. "A meta-analysis of experimental research of teacher questioning behaviour". Review of Educational Research, 51, 237-245.

Rudduck, J., D. Arnot, M. Fielding, D. McIntyre, and J. Flutter. 2003.Consulting Pupils about Teaching and Learning. Final Report to the ESRC Teaching and Learning Research Programme.

Rudduck, J. 2002. "The transformative potential of consulting young people about teaching, learning and schooling".Scottish Educational Review, 34 (2) 123-137.

Saville-Troike, M. 1989.The ethnography of communication: An introduction. Oxford: Blackwell.

Scheibman, J. 2007. "Subjective and intersubjective uses of generalizations in English conversations." In Stance-taking in Discourse, ed. R. Englebretson. Amsterdam: John Benjamins.

Schiffrin, D. 1994.Approaches to discourse. Oxford: Blackwell.

Scollon, R. 2006.Analyzing Public Discourse: Discourse Analysis in the Making of Public Policy. London: Routledge.

Scott, M. 2005.Wordsmith Tools. Software. Oxford: Oxford University Press. 
Stables, A. 2012. Be(com)ing Human : Semiosis and the Myth of Reason. Rotterdam: Sense.

Stenström, A., G. Andersen, and I.K. Hasund. 2002. Trends in Teenage Talk. Amsterdam: Benjamins

Stenström, A. and A. Jorgensen. 2009. Youthspeak in a multilingual perspective. Amsterdam: Benjamins.

Tagliamonte, S. and D. Denis. 2008. “Linguistic Ruin? LOL! Instant Messaging and Teen Language." American Speech 83 (1) 3-34.

Talmy, S. 2011." The interview as collaborative achievement: Ideology, identity, and interaction in a speech event". Applied Linguistics32, 25-42.

Thurlow, C. 2001. "Talkin' 'bout my communication: Communication awareness in early adolescence". Language Awareness, 10 (2) 213 -231.

Thurlow, C. 2003.“Teenagers in communication, teenagers on communication.”Journal of Language \& Social Psychology 22 (1) 50-57

Thurlow, C. 2005.“Deconstructing adolescent communication”. In Talking adolescence: Perspectives on communication in the teenage years, eds. A. Williams and C. Thurlow. New York: Peter Lang.

Thurlow, C. 2007. "Fabricating youth: New-media discourse and the technologization of young people". In Language in the Media: Representations, Identities, Ideologies, eds. S. Johnson and A. Ensslin. London: Continuum. 
Thurlow, C. and A. Marwick. 2005. "Apprehension versus awareness: Toward more critical understandings of young people's communication experiences." In Talking adolescence: Perspectives on communication in the teenage years, eds. A. Williams and C. Thurlow. New York: Peter Lang.

Van Dijk, T. 2012."The Role of the Press in the Reproductionof Racism" In Migrations: Interdisciplinary Perspectives, eds.M. Messer, R. Schroeder, and R. Wodak. Springer: Wien.

Williams, A. and P. Garrett. 2002."Adults' perceptions of intergenerational Communication: From adolescent storm and stress to elder aches and pains." Journal of Language and Social Psychology 21, 101-126.

Wyn, J. 2005. "Youth in the media: adult stereotypes of young people" In Talking adolescence: Perspectives on communication in the teenage years, eds. A. Williams and C. Thurlow. New York: Peter Lang.

Wolf, A. 2011. Review of vocational education: The Wolf report. London: Department forEducation. 